\title{
SHARING KNOWLEDGE THROUGH OPEN AND DISTANCE E-LEARNING EDUCATION: GLOBALIZING UNIVERSITAS TERBUKA
}

\author{
Mani Festati Broto \\ Universitas Terbuka, Indonesia \\ e-mail: mani@ecampus.ut.ac.id
}

\begin{abstract}
Universitas Terbuka (UT) as an open and distance e-learning institution in Indonesia, has widely intensify the interconnectivity on international stages. UT adopts international academic standard and pave its vision "to provide access to a world quality higher education for all through open and distance higher education". Although, most of UT students do not yet have access to adequate internet connection, UT has been a reference for other open education institutions and was acknowledged by the global community to have been succeeded in managing distance education system. By outlining the concept of education diplomacy creates an explanation that the growth of globalized educational collaboration increases the importance of conveying people-to-people engagement through e-learning education system. In previous years, UT has aimed the mission toward an ASEAN distance education collaboration and offer an Open Online Certificate Program through MOOC (Massive Open Online Courses). The aim is to share knowledge among Indonesian and its counterparts in ASEAN.
\end{abstract}

Keywords: ASEAN collaboration, educational diplomacy, MOOC, people-to-people engagement

\section{INTRODUCTION}

The globalized world demands the acceptance of the increasing international actors both state and civil society to create learning environment that is accessible to all (See UNESCO EFA 2012). UNESCO believes that education is a human right for all throughout life and that access must be matched by quality. Its mission is to build peace, eradicate poverty and drive sustainable development. Using education diplomacy perspective, this article aims to address the changes in the practice of diplomacy (new diplomacy) as a tool in reaching the basic of human right in education. In the last few decades, the importance of people-to-people engagement on specific issues concerning their daily life becomes visible-reducing the formal role of national actors in the international arena. Also, with the emergence of internet, new form of people-to-people became possible.

In 2000, The World Forum in Dakar committed to make education a basic human rights a reality. The Education for All (EFA) movement, with 164 countries joined in providing quality basic education for all children, youth and adults. This action comes after the declaration of 1990 in Thailand. In the 2000 EFA assessment report "highlights the gains and shortfalls in educational provision, pinpoints problem areas and unreached groups, and served as a blueprint for future action". Base on the above declaration, throughout the years UT has set the dimension of open and distance e-learning education firmly situated its position of making (higher) education for all. The ever growing interconnectivity brought forward by internet in an open and distance e-learning education 
provide UT with challenges and opportunities to disseminate the process of learning. UT is now entering the $5^{\text {th }}$ generation, evolving the process of e-teaching and e-learning and promote 'the virtual teaching-learning'.

For this reason, UT as an open and distance e-learning institution in Indonesia has widely and intensify the interconnectivity at international levels. This article discusses also the increasing participation of UT in the international stages. As to meet the challenges of providing higher education for all, UT adopt international academic standard and pave its vision "to provide access to a world quality higher education for all through open and distance higher education". Despite the fact, that 70 percent of UT students do not have access to adequate internet connection, UT has been a reference for other open education institutions and was acknowledged by the global community to have been succeeded in managing distance education system.

UT is member of two international institutions that focus and concerned with the quality of good practices of open and distance education. UT is also an active member of the International Council for Open and Distance Education (ICDE). For this reason, UT received ISA certificate (ICDE International Council for Open and Distance Education- Standard Agency), an international organization that provides global expertise and networks to open, distance, flexible and online education. ICDE membership includes agencies, educational authorities, commercial actors and individuals, who were all concerned with the universal right to education for all. Internal accreditation is also required because UT is a state university that has the task of maintaining the quality of higher education and provide assurance for public accountability. Also, UT has to acknowledge the importance of practicing good corporate governance in management system. UT is also a member of AAOU (Asian Association of Open Universities) an organization in Asian countries which provide members the opportunity to exchange knowledge and experience in open and distance learning $(O D L)$ and increase the capacity of AAOU member through collaborative research activities and staff visits.

Table 1. The practice of Distance Education System at UT

\begin{tabular}{c|c|c}
\hline $\begin{array}{c}\text { International } \\
\text { References }\end{array}$ & $\begin{array}{c}\text { National } \\
\text { References }\end{array}$ & $\begin{array}{c}\text { Internal } \\
\text { Audit }\end{array}$ \\
\hline International Council for & The National & Internal Audit ISO in \\
Open and Distance & Acreditation Board for & $\begin{array}{c}\text { Quality Management } \\
\text { Education (ICDE) }\end{array}$ \\
Higher Education & System \\
Standards Authority (ISA) & (BAN-PT) & \\
\cline { 2 - 3 } & Quality Management & Internal Financial \\
& System (ISO & Control System (SPI) \\
& $9001: 2008)$ & \\
\hline
\end{tabular}

With the number of 299.317 active students by Juni 2016, UT is classified in "The Top Ten Mega University of the World" and one of the founder members of "The Global Mega-University Network (GMUNET). Among the 299.317 active students, $71,16 \%$ are women. UT students spread throughout Indonesia and also abroad in six different countries (Malaysia, Singapore, Taiwan, Hongkong, South Korea and Middle East). 
Table 2. UT Students Abroad

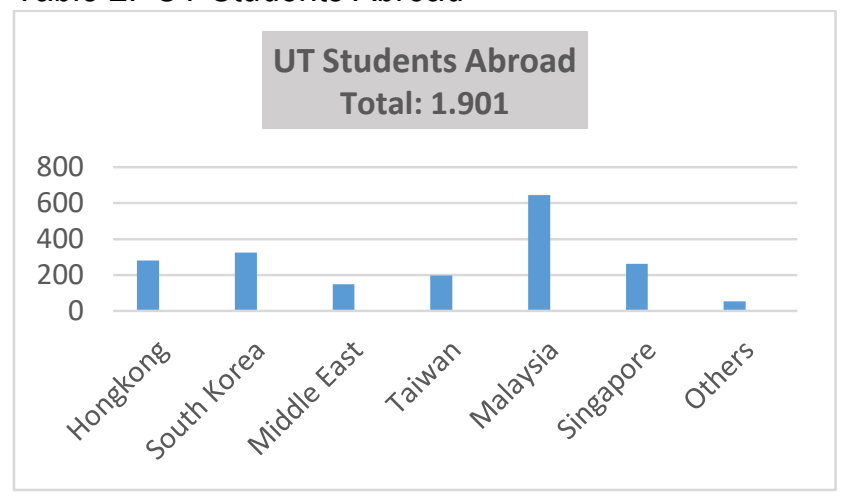

In previous years, UT participate in promoting the ASEAN Community by collaborating with Distance Education Institutions within the ASEAN countries offer an Open Online Certificate Program through MOOC (Massive Open Online Courses). With MOOCs platform, UT offers open and distance higher education for Indonesian citizens and foreigners. The goal is to share knowledge among Indonesian and its counterparts in ASEAN. The first course is titled "ASEAN STUDIES: Challenges and Opportunities For ASEAN Integration". Thus, by outlining the concept of education diplomacy creates an explanation that ASEAN collaboration increases the importance of conveying people-topeople engagement through education system. The purpose is to promote understanding the social and cultural among ASEAN community and committed to uplift the life of each community.

\section{Education Diplomacy: A new diplomacy}

In recent years, person-to-person direct diplomacy became a powerful tool to help and understand the values of learning in other culture and communities. It also nurture the change in perceptions, ideas, people and culture of each other. As we understand and agree that 'the world is becoming increasingly globalized and interdependent'

(http://campaignforeducationusa.org/blog/detail/shaping-the-concept-of-education-diplomacy).

Therefore, it is important to understand that education became an essential human rights (The World Education Forum 2000 on EFA). In respond to the UNESCO declaration, the need to ensure that all people have access to an equitable and quality education have also been the vision and mission of UT, such as the movement of 'Education for All'.

Diplomacy itself is a skill of engaging interaction by communication with other parties on basis of trust and respect. Due to globalization information technology, the interaction between parties intensify the interconnectivity of international with actors other than the formal state platforms (ministerial level diplomats). The platform of education diplomacy appears with various forms and level of interaction which means that public (private sectors, non-government organization, individuals) plays the ultimate roles of diplomacy. Education diplomacy platforms ensures the knowledge sharing between global citizens and promoting global education.

Although there is no single definition or concept of education diplomacy, in the past the term was associated with student exchange and the implication of cross-culture experience among students abroad. Today, with the same global education goal, the term education diplomacy refer also to both hard diplomacy and soft diplomacy, which implied to the areas that associated with 'the good of human-being' such policies in education, advocating funding, and in recent years it elevated as to "supporting the inclusion of education within international treaties; or using skills of persuasion to 
encourage local authorities to improve access to and the quality of education" (http://campaignforeducationusa.org/blog/detail/shaping-the-concept-of-education-diplomacy). By definition:

Education diplomacy requires a solid level of competence in cross-disciplinary knowledge and the global initiatives that are driving policies in education and human development at the international, national, and local levels. In addition, to engage in education diplomacy, one must be aware of global trends that impact communities and, therefore, have a direct and indirect effect on education.

(http://www.educationdiplomacy.org/overview/)

In the website of www.educationdiplomacy.org, the organization describes education diplomacy as 'a movement' and set five agendas as issues to be concerned and discussed globally: a) global learning assessment in education diplomacy context; b) Education Diplomacy and The World Education Forum; c) Financial for Education; d) Global Education Governance and e) Implementing Sustainable Development Goals.

Based on the above terminology, UT as one of the founding members of several international organizations in education open and distance, especially in Asian, plays a global initiatives and has an influence role in policy making in the area of open and distance system-the role of education diplomacy. This is because, other than a key members of ICDE and AAOU, UT cooperates with international organizations such as: SEAMEO (South-East Asian Ministers of Education Organization), UNESCO (United Nations Educational, Scientific and Cultural Organization), and SEAMOLEC (SEAMEO Regional Open Learning Center) in an effort to develop distance education. In previous year, as to managing higher education for relevance and efficiency, UT received assistant from the World Bank in the IMHERE Project, DBE-USAID, and OSAKA GAS Foundation as to review its curriculum and upgrade the mode of learning process and delivery.

\section{Sharing Knowledge: MOOC}

Following the declaration of EFA movement by UNESCO of 2000, in 2012 emerged a popular mode of e-learning and distance system called MOOC (Massive Open Online Course).
A Massive Open Online Course (MOOC) is an online course aimed at unlimited participation and open access via the web. In addition to traditional course materials such as filmed lectures, readings, and problem sets, many MOOCs provide interactive user forums to support community interactions among students, professors, and teaching assistants (TAs).

The MOOC emerged in response to the challenges faced by many educational organization due to an overload information through internet. MOOC is not a school or just an online course, but one way of learning by networking. The terminology of MOOC: it is a course, open, participatory, distributed and support networked life-long learning. A MOOC is an "event" because the most essential of MOOC is the way to connect and collaborate, thus engaging in learning process while at 
the time developing digital skills. Also, MOOC facilitate how people get together and discuss a topic in a more structured way.

The course is open, not because anyone can join and enroll, regardless of age, race, and gender, also it is accessible where people can take the course without paying (unless one's need a credit point). It is open because there is a shared knowledge-people can access other people's work, read and make comment. The works done by the participant and the materials put together by the facilitator are shared. The course is participatory because the outcome of the course in the completion of a specific assignment but rather engaging the material with each other works and information from internet, make connection between ideas or building network connection. MOOCs course is distributed because it is built through internet network from different parts (blog, website, video, social media etc)-there is no right way to start or end the course. Lastly, MOOC support networked life-long learning, because MOOC facilitate independence learning, where one can learn and work at their own pace. Also, one can build authentic networking and maintain the network after finishing the course. The concept of self-directed learning in a MOOC allows oneself to decide when to start and end the course and how to evaluate the process of self-learning.

Information is everywhere, with MOOC platform, this information needed to be shared and distributed-and if the shared information is useful then it become a knowledge to someone. Sharing knowledge is the cycles that needed to be maintained, because community around the world have the right to the information.

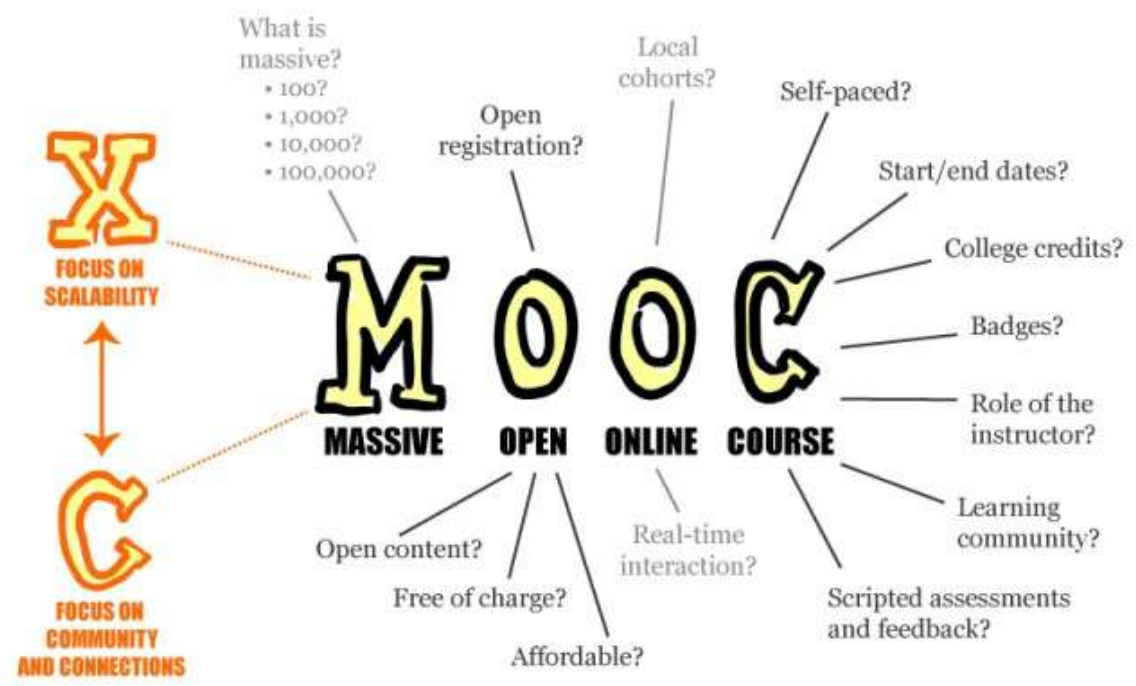

Sources: :https://en.wikipedia.org/wiki/Massive_open_online_course, accessed 18 October 2016)

Picture 1. Massive Open Online Course

\section{MOOCs UT: ASEAN Studies}

The Roadmap of ASEAN community comprised of the ASEAN Political-Security Community, ASEAN Economic Community and ASEAN Socio-Cultural Community, as well as the initiative for ASEAN Integration in year 2015. ASEAN community is a resolution to consolidate community within ASEAN to build people-to-people integration where community can enjoy human rights and build a sense of togetherness (according to the ASEAN Charter). The implementation of ASEAN community 
is to strengthened efforts in narrowing the development gap among ASEAN countries. These efforts are in line with the United Nation 2030 Agenda on Sustainable Development of ASEAN as to uplift the standards of living of the people.

In 2012, under the platform of MOOC, UT launched 7courses, and within a year increased to 14 courses, but due to limited participants, the courses was reduced again to 7 courses. The 7 courses are: ASEAN Studies, Public Speaking, Parenting, An Introduction to Moodle 2.9, Marketing, Distance Education System and Various Food Processing. In 2014, UT received assistance from UNESCO to develop MOOC-ASEAN Studies- a course which implies in accordance with the momentum of promoting ASEAN Community 2015. The course is named "ASEAN STUDIES: Challenge and Opportunity for ASEAN Integration". There are three issues that become a reference in the development course: Preventive Diplomacy, Security Issues, Economic Integration Issues. The instruction uses both English and Indonesian language. The primarily goal of the course is to give some introduction to the public about "what is ASEAN community?" It is a certified non-credit short course. The total number of participants eligible in receiving course certificate since launching is 101.

\begin{tabular}{|c|c|}
\hline $\begin{array}{l}\text { ASEAN Studies: } \\
\text { Challenges and } \\
\text { Opportunities for } \\
\text { ASEAN Integration } \\
\text { ASEAN Studies: } \\
\text { Challenges and } \\
\text { Opportunities for ASEAN } \\
\text { Integration } \\
\text { ASEAN Economic } \\
\text { Community will be } \\
\text { implemented in } 2015 . \\
\text { Course }\end{array}$ & $\begin{array}{l}\text { The Course Objective: } \\
\text { ASEAN Economic Community will be } \\
\text { implemented in 2015. This program is part of } \\
\text { the efforts to provide information to help } \\
\text { people understand about ASEAN community } \\
\text { development and its issues. This MOOCs is } \\
\text { designed for free, for anyone interested to } \\
\text { learn about ASEAN issues. This first MOOCs } \\
\text { will focus on the challenges and opportunities } \\
\text { for ASEAN integration, discussing about what } \\
\text { ASEAN was intended to become, and the } \\
\text { security as well as economic issues to be } \\
\text { resolved the motto of "One Community, One } \\
\text { Vision, One Identity." Join us in this } \\
\text { discussion. }\end{array}$ \\
\hline
\end{tabular}

Picture 2. ASEAN studies

The pedagogy of the course is 'connectivism' using Open Education Resourse (OER). The platform of the course is web based. The course is free and open to the public regardless of age, racial, gender and social economic background. The aim of the course is also to provide 'an academic space' for academic staffs to be involved in capacity building. Based on Teacher and Lecturer Law No 14 of 2005Article 1(2) stated:

Dosen adalah pendidik professional dan ilmuwan dengan tugas utama mentransformasikan, mengembangkan, dan menyebarluaskan ilmu pengetahuan, teknologi, dan seni melalui pendidikan, penelitian, dan pengabdian kepada masyarakat. (Lecturers are professional educators and scientists with the main task of transforming, developing and disseminating 
science, technology, and the arts through education, research, and community service)

The MOOC course is to facilitated lecturer in fulfilling the task of community services. UT as open and distance education institution realize that capacity building through "online community service activities" can be delivered base on the internet networking platforms. Faculty members can develop course or program using UT-MOOC also share valuable information and knowledge. The participants of the program can be anyone. In the future, UT plan to use MOOC as a platform of precourse before participants become formal UT student, such as an introduction course or 'online residential course'. The aim is to prepare student to be a self-directed learner before becoming UT student.

The topic of MOOCs ASEAN Studies are part of the course material in ASEAN Studies at UT which is specially designed as an individual course, equal to two or three credit units. The course is named "Advanced Course Program (ACP) in ASEAN Studies. The course is designed by using distance learning mode which enables flexibility for students-all courses delivered in English. The ASEAN Studies at UT aimed to strengthen mutual understanding among the ASEAN members as to welcome also the ASEAN community 2015. The course objectives:

1) Exploring and synthesizing specific and profound insights focusing on cultural, social, economic and political aspects, adopted interdisciplinary and multi-perspective approaches;

2) Comparing issues associated with practices and challenges encountered by the ASEAN countries in various sectors of development;

3) Providing critical views to the benefits and opportunities for the interactions between ASEAN and other regional communities as well as international communities from ASEAN perspectives. (Sources: Leaflet-Advanced Course Program in ASEAN Studies, PPs-Universitas Terbuka)

In practice, UT introduces student to the concept of self-directed learning during the freshmen year of the program. The main performance of self-directed learner according to Moore \& Kearsley (2012) are people who are able to:

a) decide their own learning objectives;

b) identify resources that will help them achieve their objectives

c) chose learning methods to achieve the objectives;

d) test and evaluate their performance

The ability to exercise 'learner autonomy' can be analyzed by evaluating the design of UT's course materials. UT's course material is complete with a self-instruction designed, where student can study the material on their own. UT also facilitates student with tutorial online which is not a compulsory, it is a learning services as to support student in the learning process. Using Moodle Platform, the design of the tutorial online a media of both synchronous and asynchronous for student and tutor can interact and discuss on the course topic. Hence, the tutorial online can facilitate students to interact and build networking among them. This also in line to the study of Setiani (2014) where learning in tutorial (online) occur through the interaction of social presence. In social presence and cognitive presence, add Setiani student form an online community where student collaborate and discuss the course topic, at the time student expected to think critically while reading and discussing the course topic. 




Picture 3. MOOCs UT Courses

\section{CONCLUSION}

The dimension of education diplomacy aim 'to promote peace, prosperity and sustainable solution to complex human challenges'-which is line with UNESCO mission as to eradicate poverty through education. This is to say that the basic nature in education diplomacy is people-to-people networking and collaboration. Through MOOCs ASEAN, UT plays a firmly position of global engagement and shared-knowledge among ASEAN counterparts. The ever growing interconnectivity brought forward by internet in an open and distance e-learning education provides challenges and opportunities for UT to disseminate the process of learning for all. Furthermore, the terminology of education diplomacy as a new way of diplomacy can be considered as a tool to analyze the way UT proceed in disseminating the shared knowledge globally.

\section{REFERENCES}

Moore, Michael G \& Kearsley, Greg. (2012). Distance Education: A Systems View of Online Learning, Singapore: Wadsworth Cengage Learning, pp 115.

Setiani, Made Yudhi. (2014). A Social Constructivist Learning Approach for an Online Civic Education Tutorial at Indonesia Open University, Dissertation, Faculty of Education, Simon Fraser University, Canada.

Leaflet of Advanced Course Program in ASEAN Studies, PPs-Universitas Terbuka. 


\section{Online Sources}

http://www.educationdiplomacy.org/overview/

http://unesdoc.unesco.org/images/0012/001211/121117e.pdf, The World Education Forum: Final Report, Dakar, Senegal, 26-28 April 2000.

http://www.ut.ac.id (Universitas Terbuka Website).

https://en.wikipedia.org/wiki/Massive_open_online_course, access October 2016.

http://en.unesco.org/themes/education-21st-century. 